\title{
Pengaruh Alkali dan Fraksi Volume terhadap Sifat Mekanik Komposit Serat Akar Wangi - Epoxy
}

\author{
*Akhmad Nurdin ${ }^{a}$, Sri Hastuti ${ }^{\mathrm{b}}$, Henanto Pandu D. ${ }^{\mathrm{c}}$, Rino H. ${ }^{\mathrm{c}}$ \\ aprogram Magister, Jurusan Teknik Mesin, Universitas Sebelas Maret \\ bJurusan Teknik Mesin, Universitas Tidar \\ 'Program Sarjana, Jurusan Teknik Mesin, Universitas Sebelas Maret \\ Jl. Ir. Sutami No. 36 A, Surakarta, Jawa Tengah, 57126 \\ *E-mail: akhmadnurdin.89@gmail.com
}

\begin{abstract}
The development of composite materials began to shift from synthetic fiber material to reinforced natural fiber material and is potential to be developed in Indonesia. One of the natural fibers that can be used is solid waste distilled from Vetiveria Zizanoides plant, which is still an abundant amount of root, so this waste is potential to be developed as a reinforcement in composites. The aim of this study was to determine the effect of alkali treatment and fiber volume fraction on the mechanical properties of composites. In the first study, clean fragrant fiber was soaked in alkaline solution (5\% NaoH) for 0 , 2, 4, and 6 hours. Then wash it thoroughly and leave it to dry. In the second study, the best results from the first study were used as an alkaline immersion reference, and then the variations used were fiber volume fractions of 10\%, 20\%, 30\%, and 40\%. The matrix used in this research is Epoxy A with Harderner B. Specimens for bending test refer to ASTM D790-02 and ASTM D 5942-9 impact test. The results of the first study, the effect of alkali immersion obtained bending stresses and the value of the largest immersion was $39.05 \mathrm{MPa}$ and $8.28 \mathrm{~kJ} / \mathrm{mm} 2$ at 6-hour immersion. While the results of the second study, the effect of increasing the volume fraction of fiber obtained by bending stress and the largest impact price of $43.40 \mathrm{MPa}$ and $20.5 \mathrm{~kJ} / \mathrm{mm} 2$ at a fiber volume fraction of $20 \%$.
\end{abstract}

Keywords: vetiveria zizanoides, natural fibre, alkali treatment, volume fraction, bending stress, impact

\section{Abstrak}

Perkembangan material komposit mulai bergeser dari bahan serat sintetis menjadi bahan berpenguat serat alam dan sangat potensial untuk dikembangkan di Indonesia. Salah satu serat alam yang bisa digunakan yaitu limbah padat hasil penyulingan akar wangi yang masih berupa akar dengan jumlah yang melimpah, sehingga limbah ini sangat potensial untuk dikembangkan sebagai penguat pada komposit. Tujuan dari penelitian ini untuk mengetahui pengaruh dari perlakuan alkali dan fraksi volume serat terhadap sifat mekanik dari komposit. Pada penelitian pertama, serat akar wangi yang bersih direndam larutan alkali $(5 \% \mathrm{NaoH})$ selama 0, 2, 4, dan 6 jam. Selanjutnya dicuci sampai bersih dan didiamkan sampai kering. Pada penelitian kedua,hasil terbaik dari penelitian pertama digunakan sebagai acuan perendaman alkali, selanjutnya variasi yang digunakan fraksi volume serat $10 \%$, 20\%,30\%, dan 40\%. Matrik yang digunakan pada penelitan ini adalah Epoxy A dengan Harderner B. Spesimen untuk uji bending mengacu pada ASTM D790-02 dan uji impak ASTM D 5942-9. Hasil daripenelitian pertama, pengaruh perendaman alkali didapat tegangan bending dan harga imapak terbesar $39,05 \mathrm{MPa}$ dan $8,28 \mathrm{~kJ} / \mathrm{mm}^{2}$ pada perendaman 6 Jam. Sedangkan hasil penelitian kedua, pengaruh penambahan fraksi volume serat didapat tegangan bending dan harga impak terbesar 43,40 MPa dan $20,5 \mathrm{~kJ} / \mathrm{mm}^{2}$ pada fraksi volume serat $20 \%$.

Kata kunci: akar wangi, serat alam, perlakuan alkali, fraksi volume, tegangan bending, impak

\section{Pendahuluan}

Komposit adalah material yang terdiri dari dua atau lebih material secara makroskopik dimana sifat masing-masing bahan berbeda satu sama lainnya baik itu sifat kimia maupun fisika yang terpisah [1]. Perkembangan material komposit mulai bergeser dari bahan serat sintetis menjadi bahan berpenguat serat alam. Walaupun tidak sepenuhnya menggeser serat sintetis, serat alam sebagai penguat komposit memiliki keunggulan, yaitu densitas yang relatif ringan, kekuatan dan kekakuan relatif cukup tinggi, dan lebih ramah lingkungan [2].

Tanaman akar wangi (Vetiveria zizanoides) merupakan salah satu jenis tanaman serat (bast fiber) yang tumbuh subur di Indonesia seperti di daerah Garut Jawa Barat. Tanaman akar wangi lebih banyak diambil akarnya yang digunakan sebagai penghasil minyak atsiri melalui proses penyulingan dan menghasilkan limbah padat yang masih dalam bentuk akar [3] .Tahun 2012 Kabupaten Garut memiliki potensi menghasilkan sekitar 20.000 ton lebih akar 
wangi mentah pertahun [4]. Selain Di Kabupaten Garut, tamanan akar wangi juga banyak dijumpai di Sukabumi dan Wonosobo. Akar dari tanaman akar wangi memiliki sifat yang sangat ringan dan bersifat mengapung di air, densitas dari akar ini yaitu $0,6455 \mathrm{~g} / \mathrm{cm}^{3}$ [5]. Gambar 1 dan 2 menunjukkan serat akar dari tanamanan akar wangi yang sebelum dan sesudah proses penyulingan.

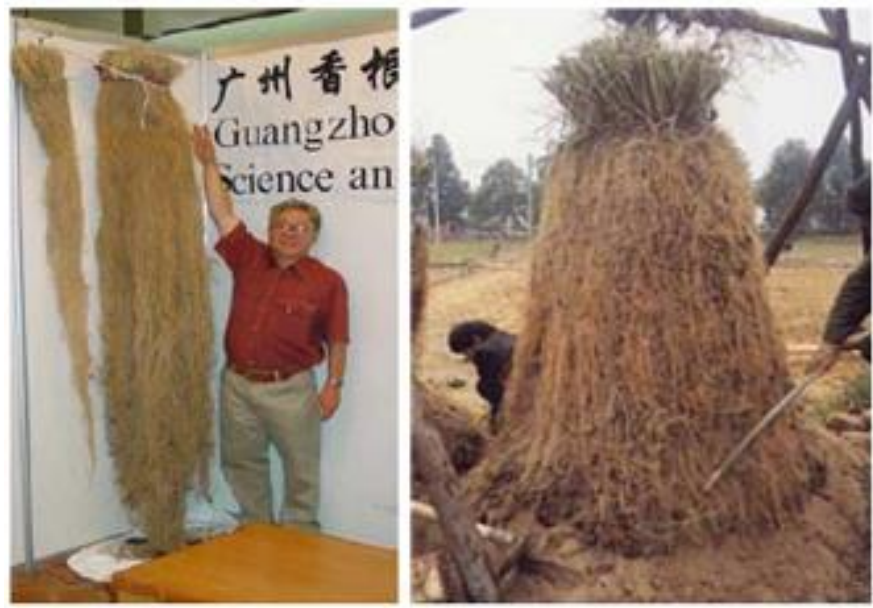

Gambar 1. Akar dari tanaman akar wangi [3]

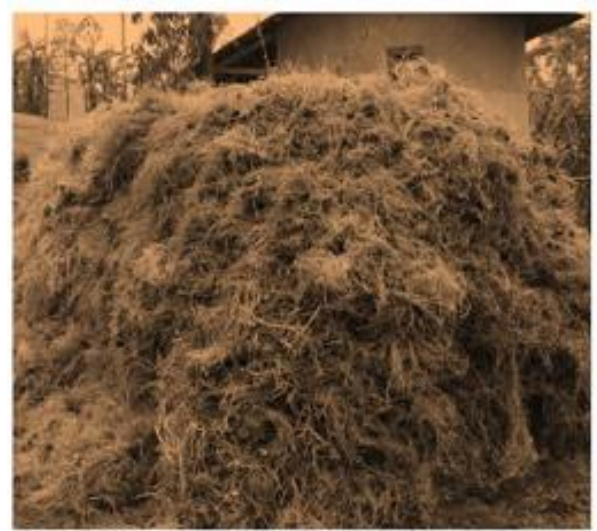

Gambar 2. Limbah padat hasil penyulingan akar wangi [3]

Permasalahan selanjutnya yang muncul adalah "bagaimana meningkatkan ikatan (mechanical bonding) antara serat dan matrik (perekat)". Peningkatan kekuatan komposit serat alam dapat dilakukan dengan 2 cara yaitu dengan memberikan perlakuan kimia serat atau dengan penambahan coupling agent. Perlakuan kimia serat yang sering dilakukan adalah perlakuan alkali seperti $\mathrm{NaOH}$, karena lebih ekonomis [6].

Perlakuan alkali atau juga disebut mercerization pada serat alam akan meningkatkan kualitas dari serat dengan mendegradasi lapisan lilin, selulosa, dan lain-lain pada permukaan serat sehingga meningkatkan rasio aspek, dan meningkatkan ikatan antarmuka antara serat dengan matriknya [7].

Diharjo [6] Melakukan penelitian tentang pengaruh alkali pada komposit serat rami - polyester dengan variasi perendaman 0 jam, 2 jam, 4 jam, dan 6 jam pada fraksi volume serat $35 \%$. Kekuatan tarik tertinggi didapat pada pengujian perlakuan alkali selama 2 jam dengan nilai 190.27 MPa. Serat rami yang diperkuat dengan perlakuan $5 \%$ $\mathrm{NaOH}$, mengindikasikan patahan tanpa adanya fiber pull out.

Hariprasad, dkk [7] Melakukan penelitian penaruh perendaman alkali serabut batang pisang - serabut kelapa pada komposit serabut batang pisang-serabut kelapa dengan matrix epoxy terhadap kekuatan impak dan kelenturan. Perendaman serabut batang pisang dilakukan pada kandungan $\mathrm{NaOH} 6 \%$ selama dua jam pada suhu ruangan, pada serabut kelapa perendaman dilakukan dengan kandungan $\mathrm{NaOH} 10 \%$ selama tiga jam pada suhu $700 \mathrm{C}$. Sedangkan fraksi berat yang digunakan yaitu 20\%. Berdasarkan pengujian didapat nilai kekuatan tarik dan nilai impak pada perlakuan alkali lebih besar dibandingkan tanpa perlakuan alkali, sedangkan pada kekuatan lentur pada serat dengan perlakuan alkali menunjuukan sedikit lebih tinggi dibandingkan tanpa perlakuan alkali.

Tran, dkk [8] Melakukan penelitian pada serat sabut kelapa pendek dengan variasi ganda yaitu perlakuan alkali dan fraksi volume. Kekuatan tarik tertinggi didapat pada pengujian perlakuan alkali dengan fraksi volume serat $20 \%$ yang memiliki nilai $27,9 \pm 1,2 \mathrm{MPa}$. Sedangkan kekuatan terendah pada pengujian tanpa perlakuan alkali dengan fraksi volume serat $50 \%$ yang memiliki nilai $15,2 \pm 1,0 \mathrm{MPa}$. 
Abanat, dkk [9] Melakukan penelitian pengaruh fraksi volume serat pelepah gebang bermatix epoxy terhadap sifat mekanik. Sebelum dilakukan pencetakan komposit, dilakukan perendaman terhadap terhadap serah dengan larutan $\mathrm{NaOH} 5 \%$ selama dua jam. Variasi fraksi volume yang digunakan pada penelitian ini adalah $0 \%, 10 \%, 20 \%, 30 \%, 40 \%$, $50 \%, 60 \%$, dan $70 \%$. Sedangkan orientasi serat yang digunakan pada penelitian ini searah, Berdasarkan hasil pengujian mekanik, didapat penambahan fraksi volume sampai 70\% akan meningkatkan nilai tegangan tarik dan impak.

Menurut Gibson [10], penempatan serat harus mempertimbangkan geometri serat, arah, distribusi, dan fraksi volume agar dihasilkan komposit berkekuatan tinggi. Fraksi volume dapat dihitung menggunakan perbandingan berikut:

$\mathrm{V} f=\frac{\text { Volume Serat }}{\text { Volume Komposit }} \times 100 \%$

Berdasarkan refensi tentang tanaman akar wangi, limbah hasil penyulingan akar wangi jumlahnya sangat berlimpah yang belum termanfaatkan secara optimal sehingga berpotensi dikembangkan sebagai serat pada komposit alami. Berdasarkan penelitian-penelitian sebelumnya menunjukkan untuk meningkatkan kekuatan mekanik komposit menggunakan serat alam, dilakukan metode perendaman dengan larutan alkali NaoH. Selain itu, fraksi volume serat pada komposit serat alam juga mempengaruhi sifat mekanik komposit. Tujuan dari penelitian ini dapat menambah nilai tambah dari limbah penyulingan akar wangi dengan sebagai bahan komposit serat alam, selain itu penelitian ini untuk mengoptimalkan kekuatan mekanik dari komposit tersebut dengan melakukan perendaman kedalam larutan alkali dan mengontrol fraksi volume pada serat akar wangi,

\section{Material dan metode penelitian}

Serat akar wangi diperoleh dari Desa Conto, Kecamatan Bulukerto, Kabupaten Wonogiri, Jawa Tengah. Pada riset pertama, serat yang sudah bersih direndam di dalam larutan alkali $(5 \% \mathrm{NaOH})$ bersirkulasi dengan variasi waktu perendaman $0,2,4$, dan 6 jam. Selanjutnya serat dinetralkan dari efek $\mathrm{NaOH}$ dengan perendaman menggunakan air bersih bersirkulasi. Setelah $\mathrm{PH}$ rendaman netral $(\mathrm{PH}=7)$, serat ditiriskan hingga kering tanpa sinar matahari. Setelah kering serat dipotong dengan panajng $\pm 5 \mathrm{~mm}$ selanjutnya mencetak spesimen bending dan impak dengan fraksi volume serat $35 \%$, kemudian diuji. Pada riset kedua dipilih pada variasi perlakuan alkali yang terbaik dan selanjutnya menggunakan variasi fraksi volume. serat, yaitu $10 \%, 20 \%, 30 \%$, dan $40 \%$ dengan proses pekerjaan yang sama pada riset pertama. Bahan matrik yang digunakan Epoxy A dan Harderner B, yang disuplai oleh PT. Justus Kimia Raya Jakarta.

Spesimen dibuat secara lembaran dan dipotong dengan menggunakan gergaji besi. Selanjutnya spesimen dihaluskan menggunakan kertas amplas. Spesimen tersebut dibuat sesuai dengan standar [11] ASTM D790-02 dan ASTM D 5942-9. Sebelum diuji, semua sepesimen dilakukan post cure pada suhu $1000{ }^{\circ} \mathrm{C}$ selama 15 menit.

Pengujian bending dilakukan menggunakan alat Universal Testing Machine atau UTM (gambar 3a) di Laboratorium Jurusan Teknik Mesin, Universitas Sebelas Maret. Pengujian impact dilakukan menggunakan impact tester izod (gambar 3b) di Laboratorium Pusat MIPA, Universitas Sebelas Maret. Foto makro (gambar 4) setelah pengujian dilakukan di Labo-atorium Jurusan Teknik Mesin, Universitas Sebelas Maret.

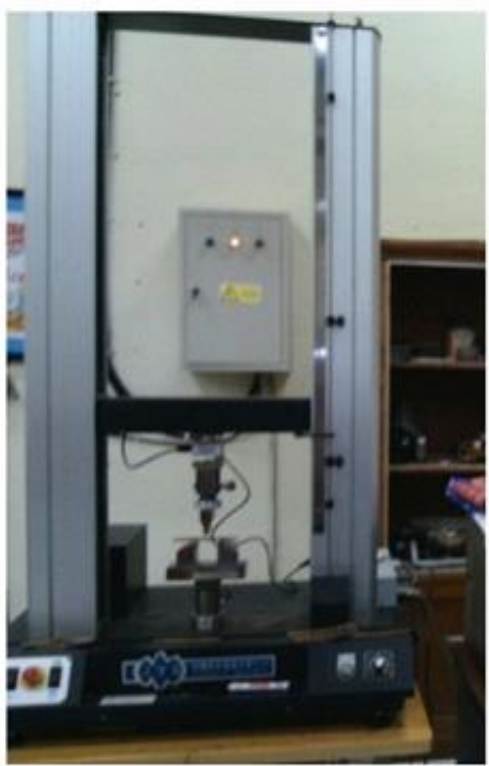

(a)

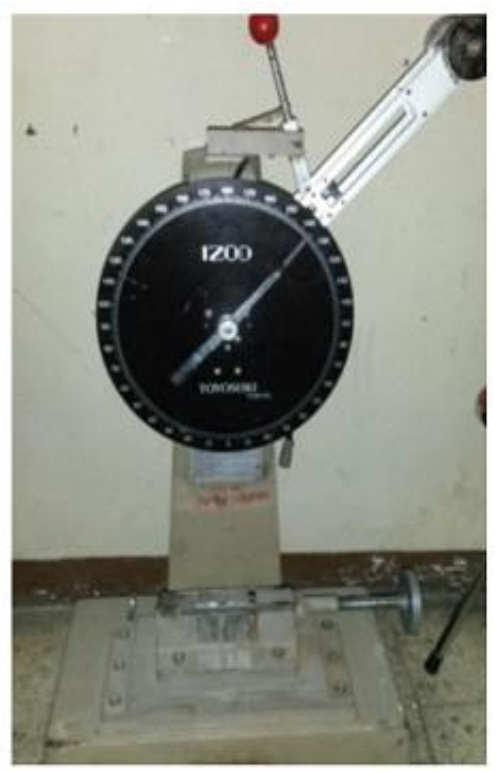

(b)

Gambar 3. (a) Alat uji bending Universal Testing Machine (UTM) (b) Alat uji impak impact tester izod 


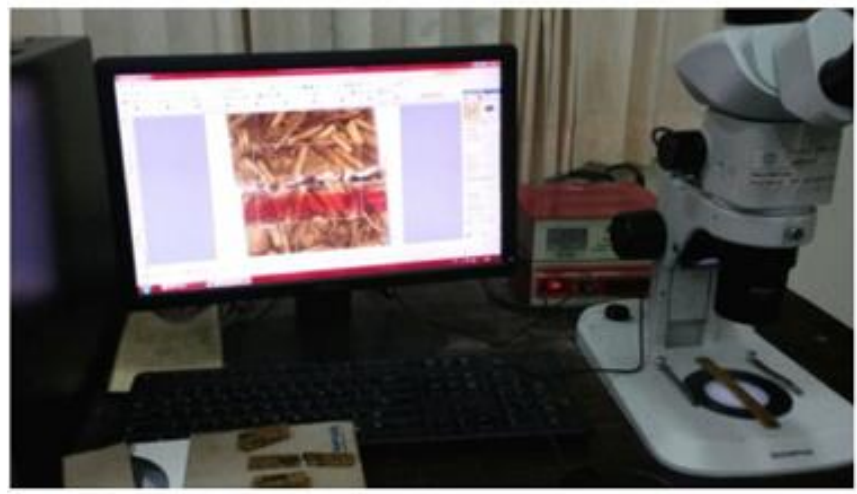

Gambar 4. Alat foto makro patahan komposit

\section{Hasil dan Pembahasan}

Gambar 4a menunjukkan hasil kekuatan bending terendah pada perendaman $\mathrm{NaOH} 5 \%$ selama 0 jam dengan nilai 15,20 MPa. Pada perendaman selama 2 jam dan 4 jam mengalami kenaikan yaitu MPa, dan 22.84 MPa. Nilai kekuatan bending naik drastis pada perendaman 6 jam dengan nilai $39.05 \mathrm{MPa}$.

Pada gambar 4b. menunjukkan hasil kekuatan impak terendah pada perendaman 0 jam dengan nilai $4.27 \mathrm{~kJ} / \mathrm{mm} 2$. Kekuatan impak secara bertahap akan naik pada perendaman serat 2 jam, 4 jam, dan 6 jam dengan nilai kekuatan impak masing-maasing $5.86 \mathrm{~kJ} / \mathrm{mm}^{2}, 7,10 \mathrm{~kJ} / \mathrm{mm}^{2}$, dan $8,28 \mathrm{~kJ} / \mathrm{mm}^{2}$.

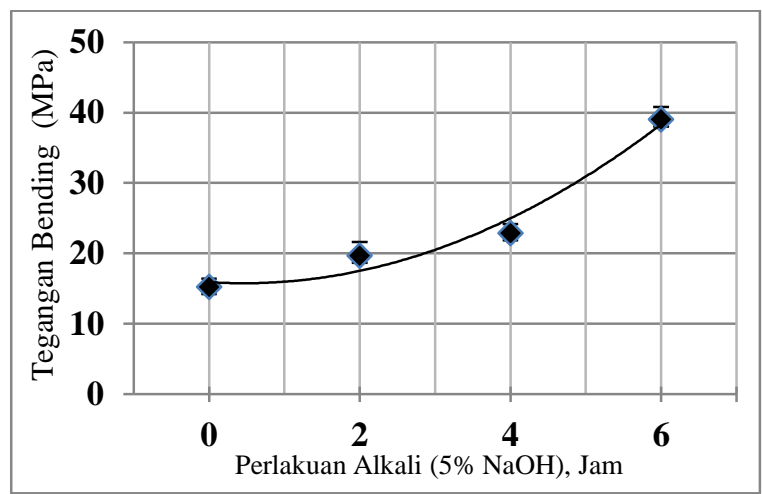

(a)

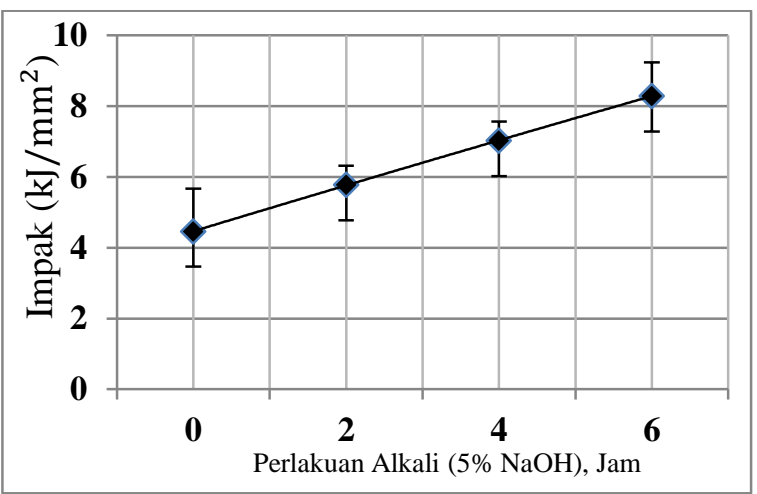

(b)

Gambar 4. Kurva hubungan tegangan Bending (a) dan impak (b) vs perlakuan alkali (5\% NaOH) pada serat

Pada komposit tanpa perendaman alkali ikatan antara serat dengan matrik tidak sempurna, hal ini disebabkan adanya lapisan yang menyerupai lilin dipermukaan serat. Sehingga ikatan/bonding antar muka (interface) antara serat dengan matrik tidak merekat dengan sempurna [6]. Komposit dengan perendaman alkali akan mengalami kenaikan nilai kekuatan yang disebabkan berkurangnya lapisan yang menyerupai lilin dipermukaan serat, sehingga ikatan/bonding antar muka (interface) antara serat dengan matrik semakin kuat [6].

Pada gambar 5a dan 5b menunjukkan tegangan bending dan impak pada rencaman alkali $\mathrm{NaOH} 5 \%$ dengan waktu 6 jam. Gambar 5a menunjukkan hasil kekuatan bending terendah pada fraksi volume serat 40\% dengan nilai 30,75 MPa. Pada fraksi volume serat 10\% nilai kekuatan bending 34,24 MPa. Nilai kekuatan bending naik pada fraksi volume serat $20 \%$ dengan nilai 43,40 MPa. Namun nilai kekuatan menurun pada fraksi volume serat 30\% dengan nilai 39,87 MPa, dan semakin menurun pada $40 \%$.

Pada gambar 5b menunjukkan hasil kekuatan impak terendah pada fraksi volume serat $10 \%$ dengan nilai 9,358 $\mathrm{kJ} / \mathrm{mm} 2$. Kekuatan impak akan naik pada fraksi volume serat $20 \%$ nilai kekuatan bending $20,5 \mathrm{~kJ} / \mathrm{mm} 2$. Selanjutnya turun pada fraksi volume serat $30 \%$ dan $40 \%$ dengan nilai $16,02 \mathrm{~kJ} / \mathrm{mm} 2$ dan $10,975 \mathrm{~kJ} / \mathrm{mm} 2$.

Komposit dengan kenaikan fraksi volume serat akan menambah kekuatan apabila matrik masih mampu mengisi antar permukaan pada serat, sehingga serat mengalami ikatan dengan matrik dengan baik. Saat komposit mengalami tegangan, maka tegangan tersebut akan terdistribusi merata dari matrik ke semua serat sampai serat tersebut mengalami kegagalan. Sedangkan komposit dengan kenaikan fraksi volume serat akan menurunkan kekuatan apabila matrik tidak mampu mengisi antar permukaan pada serat, sehingga serat mengalami ikatan yang tidak baik dengan matri. Saat komposit mengalami tegangan, maka tegangan tersebut tidak akan terdistribusi secara merata dari matrik ke semua serat, sehingga komposit akan mengalami kegagalan langsung yang disebabkan adanya void udara yang terjebak dalam komposit. 


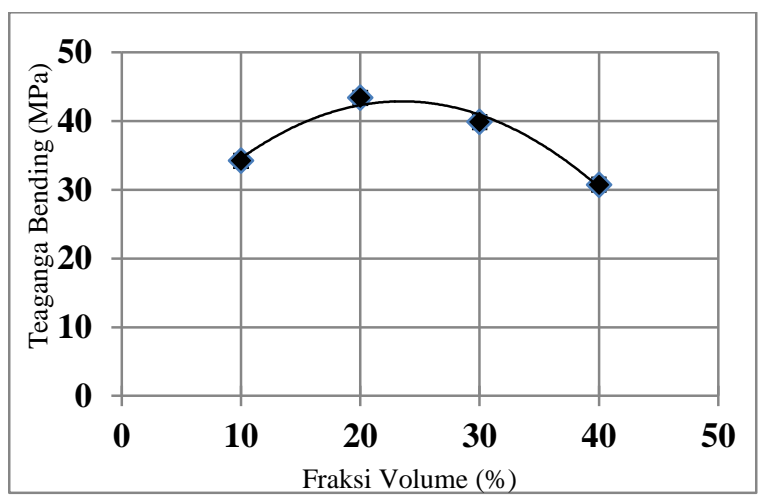

(a)

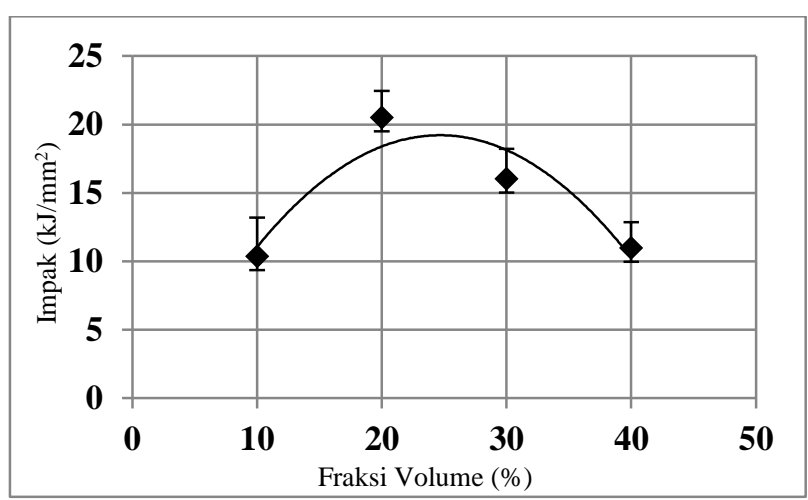

(b)

Gambar 5. Kurva hubungan tegangan Bending (a) dan impak (b) vs Fraksi Volume

Pada gambar 6a dan 6b merupakan penampang komposit tanpa perendaman dan dengan rendaman alkali. Gambar 6.a menunjukkan mekanisme fibre pull out yang terjadi pada serat tanpa perendaman alkali, dengan ikatan yang tidak kuat antara serat dan matrik saat komposit terkena beban maka serat akan terlepas dari matrik. Pada gambar 6.b menunjukkan mekanisme patahan pada serat pada serat dengan perlakuan alkali, dengan ikatan yang kuat antara serat dan matrik saat komposit terkena beban maka serat akan menahan distribusi tegangan yang terjadi sampai serat mengalami kegagalan (patah).

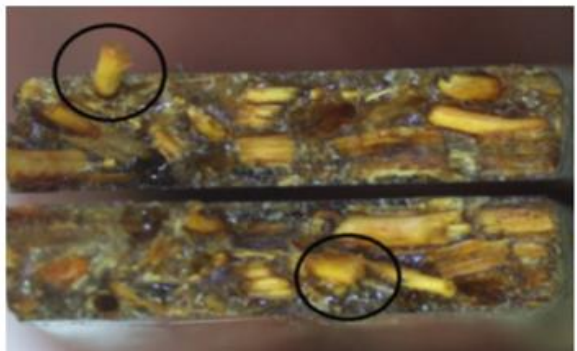

(a)

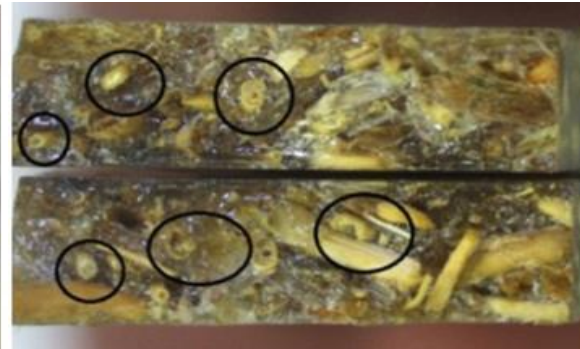

(b)

Gambar 6. (a) Penampang komposit tanpa perendaman alkali (b) Penampang komposit dengan perendaman alkali

Pada gambar 7a dan 7b menunjukkan penampang patahan komposit berdasarkan fraksi volume. Gambar 7.a menunjukkan mekanisme komposit dengan ikatan yang baik antara serat dengan matrik, sehingga saat pembebanan maksimum serat akan menahan distribusi tegangan dari matrik sampai serat mengalami kegagalan (patah). Pada gambar 7.b menunjukkan terdapat banyak lubang-lubang yang tidak terisi oleh matrik, hal ini disebabkan jumlah volume matrik yang tidak mampu mengisi antarmuka serat, sehingga udara akan terjebak didalam komposit dan menyebabkan timbulnya void.

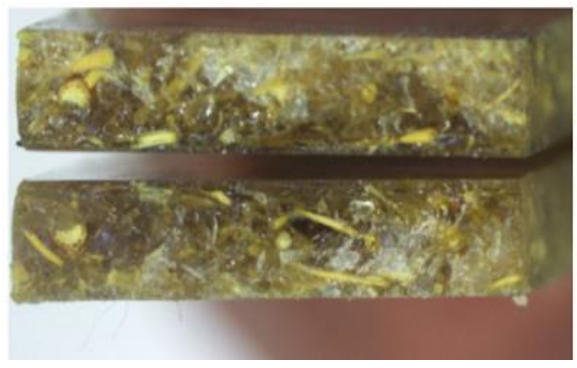

(a)

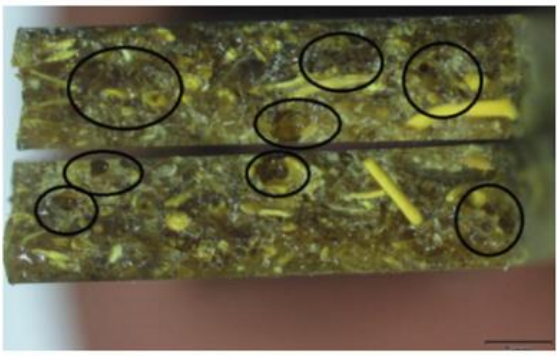

(b)

Gambar 9. (a) Penampang komposit dengan serat sedikit (b) Penampang komposit dengan serat banyak

\section{Kesimpulan}

Berdasarkan hasil dan pembahasan penelitian ini komposit yang diperkuat dengan serat akar wangi semakin lama dilakukan perendaman alkali 5\% $\mathrm{NaOH}$ sampai 6 jam memiliki nilai kekuatan bending dan impak semakin naik. Sedangkan semakin banyak fraksi volume serat melebihi $20 \%$, maka nilai kekuatan bending dan impak semakin menurun. Penampang patahan komposit yang diperkuat serat akar wangi tanpa perlakuan didominasi perilaku kegagalan fibre pull out. Sedangkan pada komposit yang diperkuat serat dengan perlakuan $5 \% \mathrm{NaOH}$, penampang patahannya mengindikasikan tanpa adanya fibre pull out. Komposit dengan fraksi volume serat lebih dari $20 \%$ akan 
menurunkan kekuatan apabila matrik tidak mampu mengisi antar permukaan pada serat, sehingga terjadi ikatan serat dengan martik tidak kuat.

\section{Referensi}

[1] Thomas, S., Joseph, K., Kumar, S,. Goda, K., and Sadasivan, M. (2012). Polymer Composites : Volume1, First Edition. Edited by 2012 Wiley-VCH Verlag GmbH \& Co .KGaA. Published 2012 by Wiley-VCH Verlag GmbH \& Co.KGaA.

[2] Jamasri .(2008). Prospek Pengembangan Komposit Serat Alam Di Indonesia. Pidato Pengukuhan Jabatan Guru Besar pada Fakultas Teknik Universitas Gadjah Mada.

[3] Guenther, E. (1990). Minyak Atsiri. Jilid IV-A. UI-Press, Jakarta.

[4] Bappeti. (2012). Java Vetiver Rootoil (Akar Wangi). Redaksi Buletin Kontrak Berjangka.

[5] Thinh L, Thai T, and Yen B (2012). Root characteristics of some grass species on the sea dikes in Viet Nam. Delft University of Technology.

[6] Diharjo, (2006). Pengaruh Perlakuan Alkali terhadap Sifat Tarik Bahan Komposit Serat Rami-Polyester. Jurusan Teknik Mesin Fakultas Teknik Universitas Sebelas Maret.

[7] T. Hariprasad, G. Dharmalingam, and P. Praveen, "Study of Mechanical Properties of Banana-Coir Hybrid Composite Using Experimental and Fem Techniques," vol. 4, no. June, pp. 518-531, 2013.

[8] Tran, N.H., Ogihara, S., and Kobayashi, S. .(2011). Mechanical Properties of Short Coir/PBS Biodegradable Composites: Effect of Alkali Treatment and Fiber Content. 18TH International Conference nn Composite Materials.

[9] J. Daud, J. Abanat, A. Purnowidodo, and Y. S. Irawan, "Pengaruh Fraksi Volume Serat Pelepah Gebang ( Corypha Utan Lamarck ) Terhadap Sifat Mekanik Pada Komposit Bermatrik Epoksi,” vol. 3, no. 2, pp. 352-361, 2012.

[10] Gibson, R., F., .(1994). Principles of Composite Material Mechanics. McGraw-Hill, New York.

[11] ASTM, “Annual Book of ASTM Standard” West Conshohocken, 2003 